\title{
Effect of Nd:YAG Laser Combined with Fluoride on the Prevention of Primary Tooth Enamel Demineralization
}

\author{
Danielle Torres AZEVEDO ${ }^{1,2}$ \\ Juliana Jendiroba FARAONI-ROMANO2 \\ Juliana dos Reis DERCELI ${ }^{2}$ \\ Regina Guenka PALMA-DIBB ${ }^{2}$ \\ Department of Pediatric Clinic, Preventive and Community Dentistry, Dental School, \\ USP - University of São Paulo, Ribeirão Preto, SP, Brazil \\ Department of Restorative Dentistry, Dental School, USP - University of São Paulo, Ribeirão Preto, SP, Brazil
}

\begin{abstract}
Most studies dealing with the caries preventive action of Nd:YAG laser have been done in permanent teeth and studies on primary teeth are still lacking. The aim of this study was to evaluate in vitro the effect of Nd:YAG laser combined or not with fluoride sources on the acid resistance of primary tooth enamel after artificial caries induction by assessing longitudinal microhardness and demineralization depth. Sixty enamel blocks obtained from the buccal/lingual surface of exfoliated human primary molars were coated with nail polish/wax, leaving only a $9 \mathrm{~mm}^{2}$ area exposed on the outer enamel surface, and randomly assigned to 6 groups $(\mathrm{n}=10)$ according to the type of treatment: $\mathrm{C}$-control (no treatment); APF: $1.23 \%$ acidulated phosphate fluoride gel; FV: $5 \%$ fluoride varnish; L: Nd:YAG laser $0.5 \mathrm{~W} / 10 \mathrm{~Hz}$ in contact mode; APFL: fluoride gel + laser; FVL: fluoride varnish + laser. After treatment, the specimens were subjected to a des-remineralization cycle for induction of artificial caries lesions. Longitudinal microhardness data (\%LMC) were analyzed by the Kruskal-Wallis test and demineralization depth data were analyzed by oneway ANOVA and Fisher's LSD test $(\alpha=0.05)$. APFL and APF groups presented the lowest percentage of microhardness change $(p<0.05)$. Demineralization depth was smaller in all treated groups compared with the untreated control. In conclusion, Nd:YAG laser combined or not with fluoride gel/varnish was not more effective than fluoride alone to prevent enamel demineralization within the experimental period.
\end{abstract}

Key Words: enamel dental, primary teeth, Nd:YAG laser, fluoride.

\section{INTRODUCTION}

The use of lasers in caries prevention was first suggested in 1972 using a ruby laser, since then, many investigations related to the application of other lasers, such as argon, $\mathrm{CO}_{2}$, and Nd:YAG lasers, in the area of preventive dentistry, have been carried out and laser irradiation has been proposed as an adjunct to conventional caries prevention therapies (1). The effect of Nd:YAG laser on the ultrastructure of enamel and its ability to reduce acid demineralization is still controversial. While some authors indicated that human enamel irradiated with the Nd:YAG laser enhance resistance to artificial caries-like formation (2), other have reported that the Nd:YAG laser did not increase acid resistance of subsurface enamel (3).
The combination of Nd:YAG laser and topical fluoride application has been suggested to decrease acid demineralization of enamel of permanent teeth (4), but only few studies have assessed the interaction of this laser combined or not with topical fluoride with the enamel of primary teeth (5-9). The ideal conditions of use of Nd:YAG laser in caries prevention have not yet been elucidated, especially in primary teeth, which have a fundamental role in the development and stabilization of the stomatognathic system, contributing on the masticatory function, esthetics and space maintaince for the permanent successors.

The aim of this in vitro study was to evaluate the effect of Nd:YAG laser combined or not with fluoride on the acid resistance of primary tooth enamel after artificial caries induction. 


\section{MATERIAL AND METHODS}

\section{Experimental Design}

The factor under study was primary tooth enamel surface treatment at 6 levels: no treatment (control), $1.23 \%$ acidulated phosphate fluoride gel, Nd:YAG laser, $5 \%$ fluoride varnish, $1.23 \%$ acidulated phosphate fluoride gel + Nd:YAG laser, and fluoride varnish + $\mathrm{Nd}$ :YAG laser. The experimental units consisted of 60 enamel blocks from the buccal and lingual surface of exfoliated human primary teeth. The specimens were randomly assigned to 6 groups $(\mathrm{n}=10)$, according to the surface treatment. The quantitative response variables were the enamel longitudinal Knoop microhardness test and the demineralization depth evaluated by optical microscopy (mm).

\section{Specimen Preparation}

Thirty exfoliated human primary molars (from the Human Tooth Bank of the Ribeirão Preto Dental School - USP) stored in $1.0 \%$ formaldehyde solution were used in this investigation. The teeth were thoroughly cleaned with a hand scaler and rubber cup/pumice prophylaxis and were stored in distilled water. The root portion, if present, was sectioned approximately $1.0 \mathrm{~mm}$ below the cementoenamel junction and the crown of each tooth was bisected in a mesiodistal direction providing two blocks (one buccal and one lingual). The resulting 60 blocks were ultrasonically cleaned in distilled water for $15 \mathrm{~min}$ and inspected for surface defects with the aid of a magnifying lens. Then, a piece of adhesive tape was attached on the flattest portion of the buccal and palatal surfaces and the specimens were coated with two layers of nail polish and melted wax. After complete drying of the coating, the tape was removed, leaving a window of approximately $9 \mathrm{~mm}^{2}(3 \times 3 \mathrm{~mm})$ of exposed enamel.

\section{Treatments}

The specimens were randomly assigned to 6 groups $(\mathrm{n}=10)$ and were subjected to treatment of enamel surface according to the following group distribution: C- Control group (no treatment); APF: application of $1.23 \%$ acidulated fluoride gel (DFL S.A., Rio de Janeiro, RJ, Brazil) on the exposed enamel area for 4 min and thereafter was removed with gauze; L: Nd:YAG laser. The equipment used for surface treatment with the Nd:YAG laser was the Smart File (Deka Laser Technologies, Firenze, Italy) emitting at $1.064 \mu \mathrm{m}$ wavelength. The laser beam was delivered in the contact mode perpendicular to the specimen surface through a quartz fiber with a diameter of $300 \mu \mathrm{m}$ and irradiation time of $15 \mathrm{~s}$. This laser system had a pulse length of 350 $\mu$ s (short-pulsed). The parameter settings were $50 \mathrm{~mJ}$ energy, $70.7 \mathrm{~J} / \mathrm{cm}^{2}$ fluence, $10 \mathrm{~Hz}$ repetition rate and $0.5 \mathrm{~W}$ power; $\mathrm{FV}$ : application of $5 \%$ fluoride varnish (Duraphat Wöel Pharma Co., Germany) on enamel surface for $24 \mathrm{~h}$ and thereafter removal with scalpel blade; APFL: application of $1.23 \%$ acidulated fluoride gel on the exposed enamel area, followed by irradiation with Nd:YAG laser for $15 \mathrm{~s}$ and removal of the gel after 4 min of contact with tooth surface; FVL: application of 5\% fluoride varnish, followed by irradiation with $\mathrm{Nd}$ :YAG laser for $15 \mathrm{~s}$ and removal of the varnish after $24 \mathrm{~h}$ of contact with tooth surface.

After 24-h storage in distilled water at $37^{\circ} \mathrm{C}$, the specimens were subjected to challenge with acid.

\section{pH Cycling}

The $\mathrm{pH}$ cycling mode described by Featherstone et al. (10) and modified by Serra and Cury (11) was used on a daily basis to produce caries lesion via a demineralization challenge followed by a remineralization period. The specimens were individually immersed in $7 \mathrm{~mL}$ of a demineralizing (DES) solution $(2 \mathrm{mmol} / \mathrm{L}$ of calcium, $2 \mathrm{mmol} / \mathrm{L}$ phosphate and $75 \mathrm{mmol} / \mathrm{L}$ acetate, $\mathrm{pH} 4.6$ ) for $6 \mathrm{~h}$, followed by rinsing with distilled and deionized water for $10 \mathrm{~s}$ and gentle drying with absorbent paper. Then, the specimens were individually immersed in the same quantity of remineralizing (RE) solution (1.5 $\mathrm{mmol} / \mathrm{L}$ calcium, $0.9 \mathrm{mmol} / \mathrm{L}$ phosphate, $150 \mathrm{mmol}$ potassium chloride and $20 \mathrm{mmol} / \mathrm{L}$ cacodilate buffer, $\mathrm{pH}$ 7.0) for $18 \mathrm{~h}$. All procedures were carried out at $37^{\circ} \mathrm{C}$. RE approximated to the saturation degree with respect to the apatite minerals found in saliva and was similar to the solution used by ten Cate and Duijsters (12). The DES and RE solutions were renewed daily and the cycles were repeated for 10 days. After every 5 days, the specimens were immersed individually in the RE solution for 2 days. The experiment lasted for a total of 14 days (13).

\section{Longitudinal Microhardness (LM)}

After the in vitro cariogenic challenge, the 
specimens were ultrasonically cleaned (3L; Dabi Atlante, Ribeirão Preto, SP, Brazil) for 15 min, embedded in acrylic resin and sectioned in the cervical-occlusal direction in their central portion, bisecting the exposed enamel area subjected to the treatments. Sectioning was carried out using a water-cooled diamond saw mounted in a precision cutting machine (Minitom; Struers A/S, Copenhagen, Denmark). One fragment was used for longitudinal microhardness analysis and the other fragment was used for analysis of demineralization depth by optical microscopy (Fig. 1).

The exposed middle of specimens were polished with 600 and 1,200-grit silicon carbide paper (Hermes Abrasives Ltd., Virginia Beach, VA, USA) in a polishing machine under water cooling followed by $0.3-\mu \mathrm{m}$ alumina paste applied with the aid of a felt disc. Next, the resin cylinders containing the specimens were ultrasonically cleaned. A microhardness tester (HMV2000; Shimadzu Corporation, Kyoto, Japan) was used, and a 25 -gf load was applied for $10 \mathrm{~s}$. The specimens were individually fixed in the device in such a way that the test surface was perpendicular to the micro-indenter tip. Knoop microhardness testing was performed on the subsurface of the enamel portion, and the indentations were made at depths of 20, 40, 60, 100 and $150 \mathrm{~mm}$ of the subsurface in the same direction. In both exposed (treated) and coated (non-treated) enamel areas, three indentations equally spaced to the adjacent indentations were taken at the five depths. The averages for the exposed (treated) and for the coated (non-treated) enamel areas were calculated and then the percentage of longitudinal microhardness surface change (\%LMC) was calculated for each specimen and for each group (Fig. 1).

\section{Demineralization Depth}

Three thin slices (Fig. 1) were sectioned in the longitudinal direction with the diamond saw of the cutting machine and slice thickness was reduced by hand polishing with 600- and 1,200-grit silicon carbide paper under cooling until reaching approximately 150 $\mathrm{mm}$, checked with a micrometer caliper accurate to the nearest $0.1 \mathrm{~mm}$ (Mitotoyo, Tokyo, Japan). The slices were viewed under an optical microscope connected to a microcomputer and images of the exposed (treated) enamel area were captured and digitized. Using the AxioVision image analysis software (Karl Zeiss, Zena, Germany), five measurements (in $\mathrm{mm}$ ) were made on the exposed (treated) enamel area of each slice. The average of the slices was calculated and represented

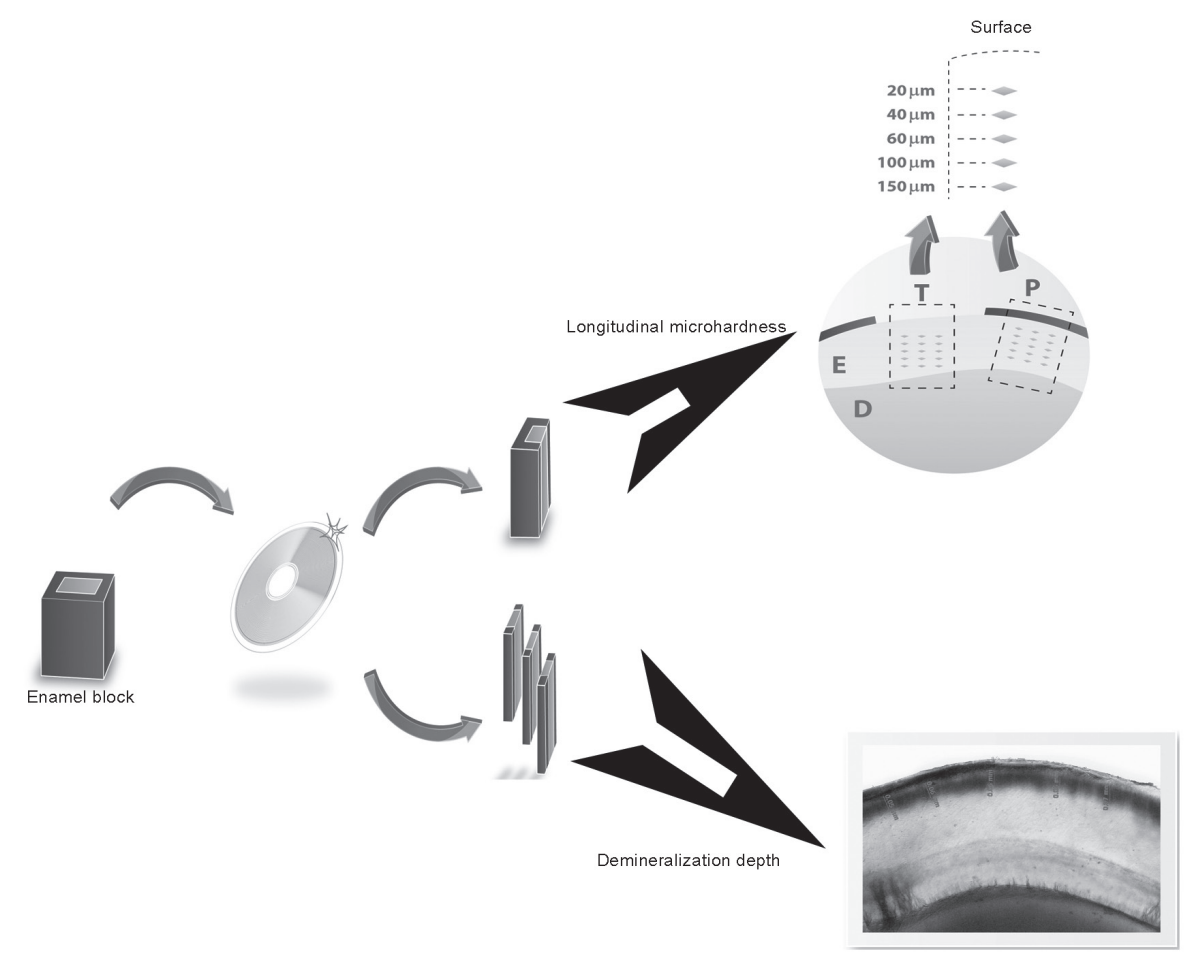

Figure 1. Schematic drawing of the specimens for analysis of longitudinal microhardness and demineralization depth. 
the demineralization depth for each specimen and for each group.

\section{Statistical Analysis}

The mean values obtained for \% $\mathrm{LMC}$ and demineralization depth were analyzed for homogeneity and normality. Data distribution for \%LMC was nonnormal and the non-parametric Kruskal-Wallis test was used. Demineralization depth data were normal and homogeneous and were analyzed by one-way ANOVA. Fisher's LSD multiple-comparison test at $5 \%$ significance level was used to verify the difference between mean values.

\section{RESULTS}

The analysis of \%LMC revealed that APF and APFL groups presented the lowest $\% \mathrm{LMC}$ median value $(\mathrm{p}<0.05)$ and $\mathrm{FV}$ and FVL groups presented intermediate \%LMC median values. The control group presented the highest \%LMC median value and was statistically similar to the L group ( $\mathrm{p}>0.05$ ) (Table 1).

The analysis of demineralization depth revealed that the Control group presented the deepest artificial caries lesions $(0.24 \pm 0.15 \mathrm{~mm})$ and differed significantly $(p<0.05)$ from the treated groups, namely APF $(0.12$ $\pm 0.03 \mathrm{~mm})$, APFL $(0.09 \mathrm{~mm}), \mathrm{FV}(0.13 \pm 0.03 \mathrm{~mm})$, FVL $(0.12 \pm 0.03 \mathrm{~mm})$ and $\mathrm{L}(0.16 \pm 0.07 \mathrm{~mm})$. No statistically significant difference $(\mathrm{p}>0.05)$ was found among the treatments with fluoride and Nd:YAG laser

Table 1. Median, mean and standard deviation of percentage of longitudinal microhardness surface change (\%LMC) for the different enamel surface treatments.

\begin{tabular}{lccc}
\hline Group & Median & Mean & s.d. \\
\hline C & $40.24 \mathrm{c}$ & 34.86 & 25.39 \\
APF & $6.21 \mathrm{a}$ & 8.42 & 8.82 \\
FV & $18.26 \mathrm{~b}$ & 21.27 & 19.29 \\
L & $33.28 \mathrm{c}$ & 35.27 & 21.07 \\
APFL & $8.77 \mathrm{a}$ & 11.57 & 12.65 \\
FVL & $21.22 \mathrm{~b}$ & 21.18 & 13.36 \\
\hline
\end{tabular}

C: no treatment (control); APF: $1.23 \%$ acidulated phosphate fluoride gel; FV: 5\% fluoride varnish; L: Nd:YAG laser 0.5 W/10 Hz on contact mode; APFL: $1.23 \%$ acidulated phosphate fluoride gel + Nd:YAG laser; FVL: fluoride varnish + Nd:YAG laser. Different letters indicate statistically significant difference. either in combination or alone.

\section{DISCUSSION}

There is no consensus in the literature regarding the ablation threshold of Nd:YAG laser, but it is known that the photoablation effect of lasers occurs only as a result of a relatively long interaction process together with high doses of accumulated energy $\left(>100 \mathrm{~J} / \mathrm{cm}^{2}\right)$ (14). Energy doses lower than $60 \mathrm{~mJ}$ do not promote tissue ablation and have been shown to increase acid resistance of the enamel of permanent teeth $(15,16)$. With such purpose, the laser parameters used in the present study were established to promote chemical and morphological alterations on enamel surface that could increase its resistance to demineralization without causing ablation or fusion. In order to alter the composition or solubility of the mineralized dental tissues to produce the caries preventive effect, the laser light must be strongly absorbed. The more radiation is absorbed by the target tissue, the lower the depth of light penetration. The light should be transformed into heat in an efficient manner without causing thermal damage to the adjacent or subjacent tissues (17). Therefore, in addition to subablative parameters, a laser system with short pulse length was used in the present study because heat propagation with short-pulse lasers is smaller, while long pulses may unnecessarily distribute energy more deeply into the tissues (18). Morever, low power density was employed to reduce risk of causing thermal damage to the tissues due to the increase of temperature.

Lasers emitting in the near infrared spectrum, such as the Nd:YAG laser, are weakly absorbed by dental hard tissues, such as enamel. For this reason, dyes such as waterproof India ink are commonly applied onto enamel surfaces before Nd:YAG laser irradiation to serve as photoabsorbers, limiting its action to the surface and reducing the possibility of energy transmission to the pulp tissue, with consequent thermal damage. However, these pigments derive from the carbon chemistry and may cause untoward chemical reactions with the production of toxic compounds to the mucosa oral (19). In addition, a previous study (13) revealed that the application of subablative energies from Nd:YAG laser without photoinitiator substances inside pits and fissures produced a more acid-resistant surface without causing fusion of dental tissue.

Some difficulties are faced when comparing the present results with those of previous studies on the 
effects Nd YAG laser irradiation on dental enamel. Firstly because most available studies used permanent teeth (4) and it is important to considerer the differences between permanent and primary substrates. In addition, there is not yet a consensus regarding the parameter settings for primary teeth, and a wide variation exists in energy density, pulse duration and mode of application of lasers, apart from different demineralization protocols (5-9). Lack of standardization shows the need of establishing safe parameters for use of lasers in caries prevention.

Recent studies in primary teeth $(8,9)$ have shown that Nd:YAG laser irradiation and combined APF treatment of the primary tooth enamel can produce a morphologically hardened enamel surface, which can be a protective barrier against acid attack (9), or even result in less mineral loss compared with the non-irradiated samples: This suggests that Nd:YAG laser could be used for enhancing primary enamel acid resistance (8).

The results of studies dealing with the effects of lasers on enamel microhardness are divergent and inconclusive, probably because of the different types of lasers, parameter settings and methodologies used in the investigations. Florin et al. (21) suggested that laser irradiation can increase enamel microhardness while Tagomori and Iwase (20), reported a decrease of microhardness in the irradiated specimens. There are also those who found no alteration on microhardness after laser irradiation (15). These conflicting findings are likely due to the use of different substrates (primary versus permanent teeth), wavelengths, parameter settings and methodologies.

In the present study, longitudinal microhardness rather than surface microhardness was evaluated after the cariogenic challenge, which is expected to reduce microhardness, permitting the analysis of hardness variation. In the present study, we found lower percentage of longitudinal microhardness change in APF and APL groups, that is, microhardness values in these groups were close to those of the coated (non-treated) enamel area. A possible explanation for this finding could be that the low $\mathrm{pH}$ of APF gel increases the formation of calcium fluoride and consequently the resistance of enamel surface to acid attack (22).

The results of the present study indicate that the Nd:YAG laser irradiation had no effect on increasing the acid resistance of enamel, diverging from the study by Banda et al. (9), which evaluated microhardness in primary teeth irradiated with Nd:YAG laser in combination with fluoride application and found a significant increase in hardness after treatment.

Previous reports in the literature $(23,24)$ referred positive results when laser was combined with fluoride in permanent teeth. However, in the present study, it cannot be affirmed that a synergism occurred because the combination of laser with $1.23 \%$ APF gel or FV produced a similar reduction on the demineralization depth to that of fluoride alone (APF and FV groups). The use of Nd:YAG laser alone or during fluoride gel/ varnish application was not more effective than topical fluoride alone in increasing the acid resistance of primary tooth enamel, which confirms the maintaince of the preventive effect of fluoride after cariogenic challenges, justifying its clinical efficacy (25). Nd:YAG laser alone was effective in reducing the demineralization depth compared with the control group, but without statistically significant difference from the groups treated with fluoride.

Considering the divergent results in the literature, further studies are necessary to evaluate whether the preventive effect of Nd:YAG laser is maintained in a long-term basis. This is a limitation of fluorides, which need constant applications to maintain its protective effect. Only if the long-term irradiation outcomes are positive and if the laser is capable of optimizing the action of fluorides, this treatment can be considered a viable alternative in the prevention of caries disease in high caries risk/activity children.

In conclusion, $\mathrm{Nd}$ :YAG laser combined or not with fluoride gel/varnish was not more effective than fluoride alone to prevent enamel demineralization within the experimental period.

\section{RESUMO}

A maioria dos estudos que utilizam o laser Nd:YAG com ação preventiva são em dentes permanentes, e são escassos os estudos em dentes decíduos. Desta forma, o objetivo do presente estudo foi avaliar in vitro o efeito do laser Nd: YAG combinado ou não com flúor na resistência ácida do esmalte decíduo após a indução de cárie artificial, através da avaliação de microdureza longitudinal e profundidade da desmineralização. Para tanto, foram selecionados 60 fragmentos de esmalte obtidos a partir da superfície bucal / lingual de molares decíduos irrompidos, os quais foram isolados com esmalte de unha e cera, deixando uma área exposta de $9 \mathrm{~mm}^{2}$ na superfície do esmalte. Os espécimes foram divididos aleatoriamente em 6 grupos $(n=10)$ de acordo com o tipo de tratamento: C- Controle: sem tratamento; APF: aplicação de gel flúor fosfato acidulado 1,23\%; FV: aplicação de verniz fluoretado 5\%; L: aplicação do Laser Nd:YAG 0,5 W/10 Hz no modo contato; APFL: aplicação de gel flúor fosfato acidulado + Laser Nd:YAG; FVL: aplicação de verniz fluoretado 5\% + Laser Nd:YAG. Após os tratamentos, os espécimes foram 
submetidos a um ciclo de des-remineralização para a indução de lesão de cárie artificial. Os dados de microdureza longitudinal (\%LMC) foram avaliados pelo teste de Kruskal-Wallis e os dados de profundidade da desmineralização foram avaliados pelos testes ANOVA e Fisher's LSD ( $\alpha=5 \%)$. Observou-se que os grupos APFL e APF apresentaram menor percentual de perda de dureza $(p<0,05)$. A profundidade de desmineralização foi menor em todos os grupos tratados em comparação com o controle. Em conclusão, o laser Nd: YAG associado ou não com flúor/verniz não foi mais efetivo do que o flúor sozinho para prevenir a desmineralização do esmalte durante o período experimental.

\section{REFERENCES}

1. Korytnicki D, Mayer MP, Daronch M, Singer Jda M, Grande RH. Effects of Nd:YAG laser on enamel microhardness and dental plaque composition: an in situ study. Photomed Laser Surg 2006;24:59-63.

2. Hossain M, Nakamura Y, Kimura Y, Yamada Y, Kawanaka T, Matsumoto K. Effect of pulsed Nd:YAG laser irradiation on acid demineralization of enamel and dentin. J Clin Laser Med Surg 2001;19:105-108.

3. Tsai CL, Lin YT, Huang ST, Chang HW. In vitro acid resistance of $\mathrm{CO} 2$ and Nd:YAG laser-treated human tooth enamel. Caries Res 2002;36:423-429.

4. Tagomori S, Morioka T. Combined effects of laser and fluoride on acid resistance of human dental enamel. Caries Res 1989;23:225231.

5. Lizarelli R, Moriyama LT, Bagnato VS. Ablation rate and micromorphological aspects with Nd:YAG picosecond pulsed laser on primary teeth. Lasers Surg Med 2002;31:177-185.

6. Birardi V, Bossi L, Dinoi C. Use of the Nd:YAG laser in the treatment of early childhood caries. Eur J Paediatr Dent 2004;5:98101.

7. Lizarelli RF, Moriyama LT, Bagnato VS. Temperature response in the pulpal chamber of primary human teeth exposed to Nd:YAG laser using a picosecond pulsed regime. Photomed Laser Surg 2006;24:610-615.

8. Castellan CS, Luiz AC, Bezinelli LM, Lopes RM, Mendes FM, De $P$ Eduardo C. In vitro evaluation of enamel demineralization after Er:YAG and Nd:YAG laser irradiation on primary teeth. Photomed Laser Surg 2007;25:85-90.

9. Banda NR, Vanaja Reddy G, Shashikiran ND. Evaluation of primary tooth enamel surface morphology and microhardness after Nd:YAG laser irradiation and APF gel treatment - an in vitro study. J Clin Pediatr Dent 2011;35:377-382.
10. Featherstone JDB, O'Really MM, Shariati M, Brugler S Enhancement of remineralization in vitro and in vivo. In: Factors relating to demineralization and remineralization of the teeth. Leach SA (ed). Oxford, IRL, 1986, p.23-34.

11. Serra MC, Cury JA. The in vitro effect of glass-ionomer cement restoration on enamel subjected to a demineralization and remineralization model. Quintessence Int 1992;23:143-147.

12. ten Cate JM, Duijsters PP. Alternating demineralization and remineralization of artificial enamel lesions. Caries Res 1982;16:201-210.

13. Correa-Afonso AM, Ciconne-Nogueira JC, Pécora JD, PalmaDibb RG. In vitro assessment of laser efficiency for caries prevention in pits and fissures Microsc Res Tech 2012;75:245-252.

14. Nelson DG, Jongebloed WL, Featherstone JD. Laser irradiation of human dental enamel and dentine. NZ Dent J 1986; 82:74-77.

15. Majori M, Manzon L, Pane S, Bedini R. Effects of Nd:YAG laser on dental enamel. J Appl Biomater Biomech 2005;3:128-133.

16. Bedini R, Manzon L, Fratto G, Pecci R. Microhardness and morphological changes induced by Nd:YAG laser on dental enamel: an in vitro study. Ann Ist Super Sanita 2010;46:168-172.

17. Featherstone JD, Nelson DG. Laser effects on dental hard tissues. Adv Dent Res 1987;1:21-26.

18. Featherstone JD, Barrett-Vespone NA, Fried D, Kantorowitz Z, Seka W. $\mathrm{CO}_{2}$ laser inhibitor of artificial caries-like lesion progression in dental enamel. J Dent Res 1998;77:1397-1403.

19. Gelskey SC, White JM, Gelskey DE, Kremers W. Vapor emissions resulting from Nd:YAG laser interaction with tooth structure. Dent Mater 1998;14:453-457.

20. Tagomori S, Iwase T. Ultrastructural change of enamel exposed to a normal pulsed Nd-YAG laser. Caries Res 1995;29:513-520.

21. Florin R, Herrmann C, Bernhardt W. Measuring microhardness of laser exposed tooth surface. Stomatol DDR 1990;40:49-51.

22. Fox JL, Yu D, Otsuka M, Higuchi WI, Wong J, Powell G. Combined effects of laser irradiation and chemical inhibitors on the dissolution of dental enamel. Caries Res 1992;26:333-339.

23. Tagliaferro EP, Rodrigues LK, Nobre Dos Santos M, Soares LE, Martin AA. Combined effects of carbon dioxide laser and fluoride on demineralized primary enamel: an in vitro study. Caries Res 2007;41:74-76.

24. Chen CC, Huang ST. The effects of lasers and fluoride on the acid resistance of decalcified human enamel. Photomed Laser Surg 2009;27:447-452.

25. Cury JA, Tenuta LMA, Ribeiro CCC, Paes Leme AF. The importance of fluoride dentifrices to the current dental caries prevalence in Brazil. Braz Dent J 2004;15:167-174.

Received July 22, 2012 Accepted December 15, 2012 